Original Research Paper

\title{
Evidences for the Role of Melatonin as a Protective Additive During Buffalo Semen Freezing
}

\author{
${ }^{1}$ Mohamed El-Raey, ${ }^{2}$ M.R. Badr, ${ }^{2}$ Z.M. Rawash and ${ }^{2}$ G.M. Darwish \\ ${ }^{I}$ Department of Theriogenology, Faculty of Veterinary Medicine, Benha University, P.O. 13736, Tokh, Kaliobia, Egypt \\ ${ }^{2}$ Artificial Insemination and Embryo Transfer Department, Animal Reproduction Research Institute, Al Haram, P. O. 12556, \\ Giza, Egypt
}

\author{
Article history \\ Received: 08-09-2014 \\ Revised: 15-09-2014 \\ Accepted: 11-12-2014 \\ Corresponding Author: \\ Mohamed El-Raey \\ Department of Theriogenology, \\ Faculty of Veterinary \\ Medicine, Benha University, \\ P.O. 13736, Tokh, Kaliobia, \\ Egypt \\ Email: mohamedelraey@ rocketmail.com \\ mohamed.metwali@fvtm.bu.edu.eg
}

\begin{abstract}
Till now, the exact role of melatonin in male infertility hasn't been fully discovered. Moreover, the intracellular signaling pathways activated by melatonin in buffalo spermatozoa especially on the level of cryopreservation process haven't been reported. The current study aimed simply to clarify the precise role of this hormone during buffalo semen cryopreservation. Semen samples were obtained randomly from 6 fertile buffalo bulls (aged 3 to 5 years). Weekly, two consecutive ejaculates were collected from each bull for successive six weeks duration using an artificial vagina. The ejaculates were pooled to eliminate variability between the evaluated samples. After that, semen samples were subjected to extension with Tris-based extender supplemented with different concentrations of melatonin $(0.1,0.25,0.5,0.75$ and $1 \mathrm{mM})$ Vs. Trisbased extender only (control). Then they were processed to cryopreservation and thawing to assess the different semen characteristics. It had been found that $0.1 \mathrm{mM}$ of melatonin significantly ( $p<0.05)$ improved post thawing motility, viability index, acrosomal integrity, total antioxidant capacity, superoxide dismutase and glutathione reductase activity. On the other hand, it significantly $(p<0.05)$ decreased the rate of lipid peroxidation, aspartate amino transferase, alanine aminotransferase, alkaline phosphatase and DNA fragmentation. All of these previously enhanced semen characteristics were reflected positively on its in vitro fertilizing capacity, as well as the percent of harvested embryos. In conclusion melatonin supplementation to the extension media of buffalo semen during processing significantly enhanced its characteristics. Moreover, the preceding results focusing more light on the potential roles of melatonin in regulating male reproduction.
\end{abstract}

Keywords: Melatonin, Buffalo, Frozen, Semen, Quality

\section{Introduction}

The sperm processing procedures used for Assisted Reproductive Techniques (ART) are aim to improve sperm quality by increasing the number of progressive motile and morphologically normal sperm cells. Sperm membrane integrity and fertilizing capacity are two indicators that might be disturbed by the action of Reactive Oxygen Species (ROS) generated by the metabolism of sperm cellular components, likes superoxide anion radical $\left(\mathrm{O}_{2-}\right)$, hydrogen peroxide $\left(\mathrm{H}_{2} \mathrm{O}_{2}\right)$ and lipid hydroperoxides, formed via lipid peroxidation of the membrane lipids of the spermatozoa
(Del Maestro, 1980; Alvarez and Storey, 2005). Lipid peroxidation usually results in irreversible loss of sperm motility and DNA damage (De Lamirande and Gagnon, 1992; Aitken, 1994; Maxwell and Watson, 1996); Ruminant semen normally contains antioxidants, including taurine, hypotaurine, Catalase (CAT) and reduced glutathione (GSH), which can offset lipid peroxidation (Jeulin et al., 1989; Griveau et al., 1995; Kantola et al., 1998). However, this endogenous antioxidative capacity may be insufficient to prevent lipid peroxidation during prolonged storage (Aurich et al., 1997). Thus the addition of external antioxidants such as melatonin might protect the sperm cells against the 
harmful effects of these oxidative stressors (ROS) and subsequently improve sperm motility during sperm storage (Ashrafi et al., 2011). Ruminant sperm seems to be especially sensitive to Reactive Oxygen Species (ROS) damage due to the relative high content of unsaturated fatty acids in their phospholipids membrane. Fluidity is linked to the integrity of the membrane lipids (Stubbs and Smith, 1984) and any change in lipid composition of the plasma membrane might therefore be associated with the cooling and storage effects. Lipid peroxidation might be one of the mechanisms responsible for the negative biochemical and physiological changes during sperm storage (Cerolini et al., 2000) and the relative low antioxidant capacity of seminal plasma (Brezezinska-Slevbodzinska et al., 1995).

Melatonin ( $N$-acetyl-5-Methoxytryptamine) is an indole derivative secreted rhythmically from the pineal gland which plays a major role in regulating the circadian clock in mammals in general and regulating the reproductive functions in particular (Reiter, 1991).

More recent studies had demonstrated that beside its multiple actions on different physiological processes, melatonin as well as its metabolites are indirect antioxidants and powerful direct scavengers that protected the cells from the free radicals brought about by their metabolism (Ahn and Bae, 2004b; 2004a; Adriaens et al., 2006; Kang et al., 2009). Melatonin exerts its effects via two specific receptors termed as $\mathrm{MT}_{1}$ and $\mathrm{MT}_{2}$ (Reppert et al., 1994; 1995).

In order to fertilize the egg, mammalian spermatozoa have to be capacitated and then undergo the acrosome reaction and hyperactivation. The acrosome reaction is a modified exocytotic event involving the acrosome (Yudin et al., 1988); that is necessary for sperm-egg plasma membrane fusion and penetration of zona pellucida (Yanagimachi, 1994). Hyperactivation is a specialized movement of the sperm flagellum that creates the propulsive force for the penetration of the zona pellucida. Hyperactivated spermatozoa exhibit large bend amplitude, whiplash and frenzied flagellar movements (Yanagimachi, 1994; Morisawa, 1994; Suarez and Ho, 2003). It was reported that melatonin significantly induced sperm hyperactivation ( $\mathrm{Si}$ and Olds-Clarke, 2000; Fujinoki, 2008). Recently, it had been demonstrated that melatonin has beneficial direct role on the other sperm characteristics like capacitationand fertilization rates (Casao et al., 2010). Furthermore, melatonin and its metabolites potently scavenge ROS (Tan et al., 2007), thus altering redoxsensitive events and preventing oxidative damage. Although physiologic levels of ROS are required for normal sperm function (Agarwal and Prabakaran, 2005), the spermatozoa have limited scavenging enzymes, thus making them highly susceptible to ROS damage (Henkel, 2005). Additionally, melatonin might be involved in the protection of different cell types against damage-induced apoptosis (Mayo et al., 1998).
So the current study aimed to clarify the role of melatonin in protection of buffalo semen from freezethawing hazards and its role in enhancing its in vitro fertilizing capacity.

\section{Materials and Methods}

\section{Diluent Preparation}

The cryoprotective extender used in the current study was composed of $2.42 \mathrm{~g}$ Tris, $1.48 \mathrm{~g}$ citric acid, $1.00 \mathrm{~g}$ fructose, $6.6 \mathrm{~mL}$ glycerol, $20 \mathrm{~mL}$ egg yolk, $25 \mathrm{mg}$ gentamicin and 50,000 IU penicillin; all of these components were dissolved in $100 \mathrm{~mL}$ deionized water and supplemented with different concentrations of melatonin.

\section{Semen Collection}

Semen samples were obtained randomly from six fertile Egyptian buffalo bulls (aged 3 to 5 y) kept at the Animal Reproduction Research Institute farm (Cairo, Egypt). Two consecutive ejaculates were collected from each bull weekly for successive six weeks using an artificial vagina. The ejaculates were pooled to eliminate variability between the evaluated samples. The semen samples were assessed for volume, sperm concentration and percentage of motile spermatozoa. The ejaculates with at least $70 \%$ motility, $800 \times 10^{6}$ sperm cells $/ \mathrm{mL}$ and $>85 \%$ normal sperm morphology were used for the present study. All experiments were done with at least 3 replicates for each group.

\section{Semen Processing}

After the evaluation of semen quality, the fresh semen samples were pooled and then split into 6 equal portions and diluted at $30^{\circ} \mathrm{C}$ with Tris-based extender supplemented with different concentrations of melatonin $(0.100,0.250,0.500,0.750$ and $1 \mathrm{mM}) \mathrm{Vs}$. Tris-based extender only (control) to obtain $120 \times 10^{6}$ sperm/mL. Melatonin (M5250-250 mg, lot No. 068k1538; Sigma-Aldrich, St. Louis, MO) stock solution was prepared by dissolving powder in the diluent media according to its dissolving capability in solutions. The required concentrations were achieved using serial dilution manner; depending on published papers (Sliwa and Stochmal, 2001; Tanyildizi el al., 2006; Di Francesco et al., 2009; Succu et al., 2011). The current work used a broad range of melatonin concentrations to determine the ideal dose that should be used for buffalo semen extension.

The fresh semen samples were transferred to pre warmed tubes. Semen was cooled from 37 to $5^{\circ} \mathrm{C}$ throughout $60 \mathrm{~min}$ in a cold cabinet. The cooled semen was loaded into $0.25 \mathrm{~mL}$ polyvinyl chloride straws (IMV, L'Aigle, France), horizontally placed in a refrigerator and kept at $4^{\circ} \mathrm{C}$ for $1 \mathrm{~h}$. These straws were then placed $6 \mathrm{~cm}$ above the liquid nitrogen surface where the temperature was approximately $-120^{\circ} \mathrm{C}$. After 15 
min, they were immersed directly into liquid nitrogen $\left(-196^{\circ} \mathrm{C}\right)$ for storage. The straws were stored at least for $24 \mathrm{~h}$ before evaluation. Frozen semen straws were thawed in water bath at $37^{\circ} \mathrm{C}$ for $30 \mathrm{sec}$. Post-thawing sperm motility; viability and acrosomal integrity were assessed according to Mohammed et al. (1998).

\section{Analysis of Sperm Motility}

The percentage of linear motile sperm was examined visually. For each extender, 3 straws were thawed separately by immersion in a water bath at $37^{\circ} \mathrm{C}$ for 30 sec. The sperm samples were placed on glass slides, covered with a glass cover and then estimated at $37^{\circ} \mathrm{C}$ by phase contrast microscope equipped with a warm stage at 200× magnifications. Sperm motility estimations were performed in 3 different microscopic fields and the mean of the 3 successive estimations was recorded as the final motility score.

\section{Analysis of Acrosomal Membrane Integrity}

Acrosomal integrity was assessed using silver nitrate stain in a procedure slightly modified from the method described by Chinoy et al. (1992). The sperm suspension was spread over slides and dried at room temperature. The preparations were fixed in ethyl alcohol $70 \%$ for 2 min and in ethyl alcohol $95 \%$ for another $2 \mathrm{~min}$. The preparations were stained with the solution $\left(\mathrm{AgNO}_{3}\right)$ for $2 \mathrm{~h}$ in an incubator at $65^{\circ} \mathrm{C}$, in complete humidity. After the preparations turned gold in colour, the chemical reaction was interrupted and the preparations were rinsed several times with distilled water. The preparations were dried at room temperature. The dried preparations were analyzed for acrosomal integrity using the Olympus BX50 light microscope with a 100-fold magnification. At least 300 sperm cells were counted per slide and the percent of acrosome intact spermatozoa was calculated.

\section{Assessment of Sperm DNA Integrity}

DNA integrity and the incidence of DNA strand breaks or fragmentation were detected using the alkaline single cell gel electrophoresis (comet) assay according to Boe-Hansen (2005). Briefly, frozen-thawed spermatozoa were diluted in phosphate buffer saline (PPS), embedded in agarose, followed by cell lysis, DNA decondensation, electrophoresis and DNA staining with $50 \mu \mathrm{L}$ of $20 \mu \mathrm{g}$ $\mathrm{mL}^{-1}$ ethidium bromide (Sigma, St. Louis, MO). The cells were then visualized by fluorescent microscopy. Intact nuclei in the comet assay appeared to have compact and brightly fluorescent heads; in contrast, strand breaks in damaged cells allow DNA migration during electrophoresis and a tail of DNA could be seen behind the head, giving the appearance of a comet (Hughes et al., 1996). After subjecting the spermatozoa to the comet assay, sperm nuclei were analyzed by computer software program (comet $I V, 2001)$.

\section{Biochemical Assays}

\section{Estimating Transaminases Enzymes}

Semen straws from each group were centrifuged at $800 \times \mathrm{g}$ for $10 \mathrm{~min}$ and supernatant was collected for estimating the Aspartate-Aminotransferase (AST); Alanine-Aminotransferase (ALT) and Alkaline Phosphatase (AKP) enzymes spectrophotometrically in all groups. Reagent kits supplied by Span diagnostics, Ltd, Surat, India were used for estimating AST, ALT and AKP as described by Reitman and Frankel (1957) and Tietz (1976). A minimum of 6 observations were recorded for each enzyme in each group.

\section{Superoxide Dismutase (SOD)}

The SOD activity was measured according to Flohe and Otting (1984). Briefly, each semen sample was diluted 1:5 with PBS ( $\mathrm{pH} 7.0)$. The assay solution contained sodium carbonate buffer $(50 \mathrm{mM}, \mathrm{pH} 10.0)$, $0.1 \mathrm{mM}$ xanthine, $0.025 \mathrm{mM}$ nitroblue tetrazolium, $0.1 \mathrm{mM}$ EDTA, xanthine oxidase and sample were mixed in a small cuvette. The SOD activity was measured at $560 \mathrm{~nm}$ on a spectrophotometer and expressed as units per milliliter.

\section{Glutathione Reductase (GSH)}

The GSH content of sperm was measured using the method of Sedlak and Lindsay (1968). The semen samples were precipitated with $50 \%$ trichloracetic acid (vol/vol) and then centrifuged at $1,000 \times \mathrm{g}$ at $22^{\circ} \mathrm{C}$ for 5 min. The reaction mixture contained $0.5 \mathrm{~mL}$ supernatant,

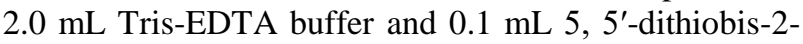
nitrobenzoic acid. The solution was incubated at $22^{\circ} \mathrm{C}$ for $5 \mathrm{~min}$ and then read at $412 \mathrm{~nm}$ on a spectrophotometer. The values of GSH were expressed as units per liter for sperm samples.

\section{Lipid Peroxidation (LPO)}

An aliquot $(500 \mu \mathrm{L})$ of semen from each sample was centrifuged at $800 \times \mathrm{g}$ for $10 \mathrm{~min}$, sperm pellets were separated and washed by resuspending in PBS and recentrifuging (three times). After the last centrifugation, $1 \mathrm{~mL}$ of deionized water was added to spermatozoa and they were snap-frozen and stored at $-70^{\circ} \mathrm{C}$ till further analysis. The samples were thawed before the lipid peroxidation assay. The concentrations of Malondialdehyde (MDA), as indices of the LPO in the sperm samples, were measured using the thiobarbituric acid reaction according to the method of Placer et al. (1966). The quantification of thiobarbituric acid reactive substances was determined comparing the absorption with the standard curve of MDA equivalents generated by the acid catalyzed hydrolysis of 1, 1, 3, 3tetramethoxypropane. The MDA concentrations were expressed in nmol/10 ${ }^{9}$. 


\section{Total Antioxidant Capacity (TAC)}

Total antioxidant capacity: Total antioxidant capacity of the frozen-thawed semen was estimated using a commercial kit (Antioxidant Capacity Assay Kit, Cayman Chemical Co. Ann Arbor, MI, USA); according to Cortassa et al. (2004).

The assay measures the capacity of the cryopreserved semen to inhibit the production of TBA Reactive Substances (TBARS) from sodium benzoate under the influence of the reactive oxygen free radicals derived from the Fenton's reaction. The reaction was measured spectrophotometrically at $532 \mathrm{~nm}$. Antioxidants from the added sample cause suppression of the production of TBARS and the inhibition of the colour development is defined as AOA. A solution of $1 \mathrm{mmol} \mathrm{L}^{-1}$ uric acid was used as standard.

\section{in vitro Maturation}

Immature buffalo oocytes were collected from fresh ovaries just after slaughter at a local abattoir. CumulusOocyte Complexes (COCs) were collected by aspiration of medium-sized (2-8 $\mathrm{mm}$ ) ovarian follicles using 18-gauge needle attached to a disposable $10 \mathrm{~mL}$ syringe. Evenly granulated oocytes surrounded with multi-layered compact cumulus cells were selected for the experiments. Selected COCs were firstly washed three times in sterile D-PBS and then washed three times in IVM medium; IVM was performed in TCM-199 medium (Earl's salt, Sigma Chemical CO., St. Louis, Mo., USA) supplemented with $10 \%$ heat inactivated fetal calf serum (FCS, Gibco, $30 \mathrm{~K}$ 0351), $10 \mu \mathrm{g} \mathrm{mL}^{-1}$ Luteinizing hormone, $5 \mu \mathrm{g} \mathrm{mL}^{-1}$ follicle stimulating hormone and $1 \mu \mathrm{g} \mathrm{mL} \mathrm{m}^{-1}$ estradiol-17ß. The oocytes were cultured for $24 \mathrm{~h}$ at $39^{\circ} \mathrm{C}$ in an atmosphere of $5 \% \mathrm{CO}_{2}$ in air with maximum humidity.

\section{in vitro Fertilization}

Three straws from each melatonin treatment were thawed in a water bath at $37^{\circ} \mathrm{C}$ for $30 \mathrm{sec}$. The most motile spermatozoa were separated by swim up technique in the fertilization medium, modified Tyrode's Albumin-LactatePyruvate (TALP) containing $6 \mathrm{mg} \mathrm{mL}^{-1}$ Bovine Serum Albumin (BSA), for $1 \mathrm{~h}$ as recorded by Parrish et al. (1988). The uppermost layer of the medium containing the most motile spermatozoa was collected and washed twice by centrifugation at $800 \mathrm{xg}$ for $10 \mathrm{~min}$. The sperm pellet was resuspended in the fertilization TALP medium containing $10 \mu \mathrm{g} \mathrm{mL} \mathrm{m}^{-1}$ heparin. After appropriate dilution, $2 \mu \mathrm{L}$ (final concentration $2 \times 10^{6}$ sperm cell $/ \mathrm{mL}$ ) of sperm suspension was added to the fertilization drops, containing in vitro matured oocytes. Gametes were co-incubated in the fertilization drops under sterile mineral oil for $18 \mathrm{~h}$ at $39^{\circ} \mathrm{C}$ in an atmosphere of $5 \% \mathrm{CO}_{2}$ in air with complete humidity.

\section{Evaluation of in vitro Fertilizing Potential}

The oocyte fertilization rate was examined on the base of the pronuclei number found in the oocyte after fertilization. In brief, the previously matured oocytes were incubated with the sperms for $6 \mathrm{~h}$ at $5 \% \mathrm{CO}_{2}$ and $20 \% \mathrm{O}_{2}$ in humid incubator; after that the oocytes were subjected to denudation with perfect handmade pipette. Then they were cultured for $10 \sim 12 \mathrm{~h}$ in CR1aa medium. They were fixed for 24 48 $\mathrm{h}$ in ethanol: Acetic acid (3:1 $\mathrm{v} / \mathrm{v})$, then stained with $1 \%$ Orcein dissolved in $45 \%$ acetic acid according to Marei et al. (2009). The oocytes were evaluated under a phase-contrast microscope (Nikon, Tokyo, Japan). Oocytes were evaluated for normal fertilization according to Martino et al. (1994), on basis of oocyte that had set of male and female pronuclei in the ooplasm were considered to be fertilized normally, while the penetration rate was evaluated by the presence of sperm tail only in the ooplasm.

\section{in vitro Culture}

Denuded zygotes were transferred into SOFaa culture medium (SOF with $1 \mathrm{mM}$ glutamine, 1\% MEM nonessential amino acids and 1\% MEM essential amino acids) according to Badr (2009) and then covered with mineral oil for 7 - days at $38.5^{\circ} \mathrm{C}$ in an atmosphere of $5 \%$ $\mathrm{CO}_{2}$ in air with maximum humidity. The cleaved oocytes were recorded after $48 \mathrm{~h}$ of insemination and those developed to the morula and blastocyst stages were recorded at 5-7 days post-insemination according to Totey et al. (1992).

\section{Statistical Analysis}

All data were analyzed by using Costat Computer Program (1986), Version 3.03 copyright Cottort Software and were compared by the Least Significant Difference least (LSD) at $5 \%$ levels of probability. The results were expressed as means $\pm \mathrm{SE}$. The mean values of the percentages of motile sperm, acrosome-intact sperm, enzyme activity and embryo development were compared using Duncan's multiple range test by oneway ANOVA procedure, when the F-value was significant $(p<0.05)$. Sperm fertilizing capacity and zygotes developmental competences were assessed using Chi-square at $(p<0.01$ and 0.05 , respectively).

\section{Results}

As shown in Table 1, there was a significant $(p<0.05)$ increase in post thawing motility of buffalo semen treated by 0.1 and $0.25 \mathrm{mM}$ of melatonin $(60.00 \pm 2.9$ and $55.00 \pm 5.01$, respectively). Moreover, there was a significant $(p<0.05)$ increase in the viability index of buffalo semen treated with 0.1 and $0.25 \mathrm{mM}$ of melatonin (157.5 \pm 11.8 and $150.83 \pm 8.21$, respectively); reflecting that these two concentrations have a beneficial protecting effect on buffalo semen post thawing characteristics than other melatonin concentrations $(0.5,0.75$ and $1 \mathrm{mM})$. 
Table 1. The effect of melatonin supplementation to buffalo semen diluent medium on sperms characteristics

\begin{tabular}{llllll}
\hline Treatment & $\begin{array}{l}\text { Dilution } \\
\text { motility }(\%)\end{array}$ & $\begin{array}{l}\text { Cooling } \\
\text { motility }(\%)\end{array}$ & $\begin{array}{l}\text { Post-thawing } \\
\text { motility }(\%)\end{array}$ & $\begin{array}{l}\text { Viability } \\
\text { Index* }\end{array}$ & $\begin{array}{l}\text { Acrosomal } \\
\text { integrity }(\%)\end{array}$ \\
\hline Control & $71.67 \pm 4.42^{\mathrm{a}}$ & $65.00 \pm 2.90^{\mathrm{a}}$ & $45.00 \pm 2.90^{\mathrm{bc}}$ & $97.00 \pm 9.09^{\mathrm{b}}$ & $17.33 \pm 0.88^{\mathrm{bc}}$ \\
Melatonin 0.1mM & $80.00 \pm 2.89^{\mathrm{a}}$ & $71.66 \pm 1.67^{\mathrm{a}}$ & $60.00 \pm 2.9^{\mathrm{a}}$ & $157.5 \pm 11.8^{\mathrm{a}}$ & $13.67 \pm 1.76^{\mathrm{c}}$ \\
Melatonin 0.25 M & $75.00 \pm 2.90^{\mathrm{a}}$ & $75.00 \pm 2.88^{\mathrm{a}}$ & $55.00 \pm 5.01^{\mathrm{ab}}$ & $150.83 \pm 8.21^{\mathrm{a}}$ & $15.00 \pm 1.73^{\mathrm{bc}}$ \\
Melatonin 0.5 mM & $68.33 \pm 6.02^{\mathrm{a}}$ & $66.67 \pm 3.34^{\mathrm{a}}$ & $43.33 \pm 4.41^{\mathrm{bc}}$ & $102.50 \pm 6.29^{\mathrm{b}}$ & $15.67 \pm 1.86^{\mathrm{bc}}$ \\
Melatonin 0.75 M & $70.00 \pm 5.78^{\mathrm{a}}$ & $65.00 \pm 7.64^{\mathrm{a}}$ & $38.66 \pm 3.34^{\mathrm{c}}$ & $95.83 \pm 4.65^{\mathrm{b}}$ & $21.33 \pm 2.03^{\mathrm{ab}}$ \\
Melatonin 1 mM & $70.00 \pm 2.89^{\mathrm{a}}$ & $63.33 \pm 6.02^{\mathrm{a}}$ & $36.66 \pm 3.34^{\mathrm{c}}$ & $66.66 \pm 4.42^{\mathrm{c}}$ & $24.66 \pm 2.96^{\mathrm{a}}$ \\
\hline
\end{tabular}

Three replications of the experiment were conducted. Results are presented as mean \pm SEM

a,b Values with different letters in the same column are significantly different $(p<0.05)$

*Viability index $=$ post-thawing motility $/ 2+$ motility after $1 \mathrm{~h}+$ motility after $2 \mathrm{~h}+$ motility after $3 \mathrm{~h}$

Table 2. The effect of melatonin supplementation to buffalo semen diluent medium on its antioxidant capacity

\begin{tabular}{llllr}
\hline Treatment & $\begin{array}{l}\text { TAC } \\
(\mathrm{m} \mu / \mathrm{mL})\end{array}$ & $\begin{array}{l}\text { SOD } \\
(\mathrm{U} / \mathrm{mL})\end{array}$ & $\begin{array}{l}\text { GSH } \\
(\mathrm{U} / \mathrm{L})\end{array}$ & $\begin{array}{c}\text { MALON) } \\
(\mathrm{nmol} / \mathrm{mL})\end{array}$ \\
\hline Control & $0.17 \pm 0.2^{\mathrm{b}}$ & $27.33 \pm 3.49^{\mathrm{c}}$ & $52.33 \pm 4.09$ & $26.00 \pm 4.04^{\mathrm{a}}$ \\
Melatonin $0.1 \mathrm{mM}$ & $0.58 \pm 0.08^{\mathrm{a}}$ & $73.67 \pm 5.37^{\mathrm{a}}$ & $106.66 \pm 12.03^{\mathrm{a}}$ & $11.00 \pm 1.73^{\mathrm{b}}$ \\
Melatonin $0.25 \mathrm{mM}$ & $0.35 \pm 0.03^{\mathrm{b}}$ & $52.66 \pm 6.07^{\mathrm{b}}$ & $83.33 \pm 4.48^{\mathrm{ab}}$ & $16.67 \pm 2.60^{\mathrm{ab}}$ \\
Melatonin $0.5 \mathrm{mM}$ & $0.31 \pm 0.06^{\mathrm{b}}$ & $36.33 \pm 4.64^{\mathrm{c}}$ & $87.67 \pm 13.06^{\mathrm{ab}}$ & $16.00 \pm 2.51^{\mathrm{ab}}$ \\
Melatonin $0.75 \mathrm{mM}$ & $0.25 \pm 0.04^{\mathrm{b}}$ & $24.33 \pm 4.38^{\mathrm{c}}$ & $73.00 \pm 7.24^{\mathrm{bc}}$ & $21.00 \pm 3.61^{\mathrm{ab}}$ \\
Melatonin $1 \mathrm{mM}$ & $0.19 \pm 0.05^{\mathrm{b}}$ & $31.00 \pm 5.51^{\mathrm{c}}$ & $59.67 \pm 10.67^{\mathrm{bc}}$ & $20.67 \pm 4.49^{\mathrm{ab}}$ \\
\hline
\end{tabular}

Three replications of the experiment were conducted. Results are presented as mean \pm SEM

a,b Values with different letters in the same column are significantly different $(p<0.05)$.

Abbreviations: TAC: Total Antioxidant Capacity; SOD: Superoxide Dismutase; GSH: Glutathione Reductase; Malon: malondialdehyde

Table 3. The effect of melatonin supplementation to buffalo semen diluent medium on its enzymatic activity

\begin{tabular}{llll}
\hline Treatment & AST $(\mathrm{U} / \mathrm{L})$ & ALT $(\mathrm{U} / \mathrm{L})$ & AKP $(\mathrm{U} / \mathrm{L})$ \\
\hline Control & $104.67 \pm 10.42^{\mathrm{a}}$ & $28.66 \pm 3.84^{\mathrm{a}}$ & $25.33 \pm 4.09^{\mathrm{a}}$ \\
Melatonin 0.1 mM & $65.33 \pm 5.90^{\mathrm{b}}$ & $14.33 \pm 2.40^{\mathrm{b}}$ & $11.33 \pm 2.40^{\mathrm{b}}$ \\
Melatonin 0.25 mM & $68.33 \pm 5.79^{\mathrm{b}}$ & $19.67 \pm 2.73^{\mathrm{ab}}$ & $15.67 \pm 2.02^{\mathrm{ab}}$ \\
Melatonin 0.5 mM & $80.33 \pm 8.3^{\mathrm{ab}}$ & $23.33 \pm 2.61^{\mathrm{ab}}$ & $19.33 \pm 4.67^{\mathrm{ab}}$ \\
Melatonin 0.75 mM & $83.67 \pm 4.06^{\mathrm{ab}}$ & $27.67 \pm 3.53^{\mathrm{a}}$ & $18.66 \pm 3.84^{\mathrm{ab}}$ \\
Melatonin $1 \mathrm{mM}$ & $94.00 \pm 8.32^{\mathrm{a}}$ & $28.00 \pm 4.04^{\mathrm{a}}$ & $22.66 \pm 3.53^{\mathrm{ab}}$ \\
\hline
\end{tabular}

Three replications of the experiment were conducted. Results are presented as mean \pm SEM

${ }^{a, b}$ Values with different letters in the same column are significantly different $(p<0.05)$.

Abbreviations: AST: Aspartate Amino Transferase; ALT: Alanine Aminotransferase; AKP: Alkaline Phosphatase

Table 4. The effect of melatonin supplementation to buffalo semen diluent medium on its DNA integrity

\begin{tabular}{llll}
\hline Treatment & DNA Fragmentation $(\%)$ & Tail length $(\mu \mathrm{m})$ & Tail moment* \\
\hline Control & $5.22 \pm 2.74^{\mathrm{a}}$ & $3.45 \pm 0.75^{\mathrm{ab}}$ & $17.43 \pm 8.03^{\mathrm{a}}$ \\
Melatonin $0.1 \mathrm{mM}$ & $2.14 \pm 0.85^{\mathrm{b}}$ & $2.12 \pm 1.01^{\mathrm{b}}$ & $4.76 \pm 3.78^{\mathrm{b}}$ \\
Melatonin $0.25 \mathrm{mM}$ & $2.78 \pm 0.85^{\mathrm{ab}}$ & $3.18 \pm 0.90^{\mathrm{ab}}$ & $8.67 \pm 2.92^{\mathrm{ab}}$ \\
Melatonin 0.5 mM & $2.64 \pm 0.59^{\mathrm{ab}}$ & $2.18 \pm 0.88^{\mathrm{ab}}$ & $6.10 \pm 3.68^{\mathrm{b}}$ \\
Melatonin 0.75 mM & $2.94 \pm 1.19^{\mathrm{ab}}$ & $4.16 \pm 1.01^{\mathrm{a}}$ & $11.44 \pm 1.99^{\mathrm{ab}}$ \\
Melatonin $1 \mathrm{mM}$ & $4.02 \pm 1.56^{\mathrm{ab}}$ & $4.62 \pm 1.37^{\mathrm{a}}$ & $18.12 \pm 7.9^{\mathrm{a}}$ \\
\hline
\end{tabular}

Three replications of the experiment were conducted. Results are presented as mean \pm SEM

a,b Values with different letters in the same column are significantly different $(p<0.05)$.

*tail moment is the result of multiplying the percent of DNA fragmentation by Tail length

Table 5. The effect of melatonin supplementation to buffalo semen diluent medium on the sperm fertilizing capacity

\begin{tabular}{lccc}
\hline Treatment & No. oocytes & Penetration rate $(\%)$ & Fertilization rate $(\%)$ \\
\hline Control & 59 & $30\left(50.84^{\mathrm{ab}}\right)$ & $14\left(23.72^{\mathrm{c}}\right)$ \\
Melatonin $0.1 \mathrm{mM}$ & 57 & $36\left(63.15^{\mathrm{a}}\right)$ & $33\left(57.89^{\mathrm{a}}\right)$ \\
Melatonin $0.25 \mathrm{mM}$ & 65 & $42\left(65.07^{\mathrm{a}}\right)$ & $27\left(41.53^{\mathrm{ab}}\right)$ \\
Melatonin $0.5 \mathrm{mM}$ & 60 & $22\left(36.66^{\mathrm{b}}\right)$ & $16\left(26.66^{\mathrm{cb}}\right)$ \\
Melatonin $0.75 \mathrm{mM}$ & 63 & $24\left(38.09^{\mathrm{b}}\right)$ & $15\left(23.80^{\mathrm{c}}\right)$ \\
Melatonin $1 \mathrm{mM}$ & 56 & $23\left(41.07^{\mathrm{b}}\right)$ & $13\left(23.21^{\mathrm{c}}\right)$ \\
\hline
\end{tabular}

Three replications of the experiment were conducted. Results are presented as mean \pm SEM

Percentages are based on the number of oocytes examined

${ }^{a, b}$ Values with different letters in the same column are significantly different $(p<0.01)$ 
Table 6. The effect of melatonin supplementation to buffalo semen diluent medium on resultant zygotes developmental competences

\begin{tabular}{|c|c|c|c|c|}
\hline Treatment & $\begin{array}{c}\text { No. } \\
\text { oocytes }\end{array}$ & $\begin{array}{l}\text { Cleavage } \\
\text { rate }(\%)\end{array}$ & $\begin{array}{l}\text { Morula } \\
\text { stage }(\%)\end{array}$ & $\begin{array}{l}\text { Blastocyst } \\
\text { stage }(\%)\end{array}$ \\
\hline Control & 49 & $12\left(24.48^{\mathrm{ab}}\right)$ & $3(6.12 b)$ & $1\left(2.04^{\mathrm{b}}\right)$ \\
\hline Melatonin $0.1 \mathrm{mM}$ & 48 & $20\left(41.66^{\mathrm{a}}\right)$ & $11(22.92 a)$ & $6\left(12.50^{b}\right)$ \\
\hline Melatonin $0.5 \mathrm{mM}$ & 49 & $11\left(22.44^{\mathrm{bc}}\right)$ & $3(6.12 b)$ & $2\left(4.08^{\mathrm{ab}}\right)$ \\
\hline Melatonin $0.75 \mathrm{mM}$ & 42 & $11\left(26.19^{\mathrm{ab}}\right)$ & $3(7.14 b)$ & $1\left(2.38^{\mathrm{ab}}\right)$ \\
\hline Melatonin $1 \mathrm{mM}$ & 46 & $8\left(17.39^{b}\right)$ & $2(4.35 b)$ & $1\left(2.17^{b}\right)$ \\
\hline
\end{tabular}

Five replications of the experiment were conducted

Results are presented as mean \pm SEM Percentages are based on the number of oocytes examined

a,b Values with different letters in the same column are significantly different $(p<0.05)$

*Table (5 and 6) not the same set of experiment. In Table 5 we stained most of oocytes by aceto-orcein stain to evaluate both penetration and fertilization rate. The remaining oocytes are few-(normally the harvested oocyte number from buffaloes ovary are few) -so not cultured for embryo development, otherwise our results in such condition will not be reliable. So Table 6 is a new experiment in which all oocytes after insemination were cultured (without staining) to evaluate embryo development.

Additionally there was a significant $(p<0.05)$ significant improvement $(13.67 \pm 1.76)$ in the sperm acrosomal integrity in the semen sample treated with $0.1 \mathrm{mM}$ of melatonin if it was compared with control and other melatonin treated semen samples.

Moreover, there was a significant increase $(p<0.05)$ in TAC, SOD and GSH activity in semen samples treated with $0.1 \mathrm{mM}$ of melatonin $(0.58 \pm 0.08$, $73.67 \pm 5.37$ and $106.66 \pm 12.03$, respectively). Furthermore, there was a significant $(p<0.05)$ decrease in the level of lipid peroxidation in the membrane of the cryopreserved buffalo spermatozoa treated with $0.1 \mathrm{mM}$ of melatonin (11.00 \pm 1.73 ), compared with control (Table $2)$. These results indicate that there was a significant enhancement in the antioxidant activity of the cryopreserved buffalo semen treated with melatonin by increasing the active enzymes that decrease the level of its lipid peroxidation; which in turn decrease the rate of its damage. Studying the effect of melatonin supplementation to buffalo semen diluent medium on its enzymatic activity reflecting that there were significant decreases $(p<0.05)$ in AST, ALT and AKP levels in melatonin treated buffalo sperm cells especially those treated with $0.1 \mathrm{mM} \quad(65.33 \pm 5.90,14.33 \pm 2.40$ and11.33 \pm 2.40 , respectively) if they were compared with the results of control $(104.67 \pm 010.42,28.66 \pm 3.84$ and $25.33 \pm 4.09$, respectively) (Table 3 ). This indicates that melatonin addition to buffalo semen resulting in obvious decrease in the rate of the sperm degradation during cryopreservation process, consequently, enhancing the sperm viability and activity. Additionally, there was a significant decrease $(p<0.05)$ in the DNA fragmentation, tail length and tail moment of buffalo semen samples treated with $0.1 \mathrm{mM}$ of melatonin $(2.14 \pm 0.85,2.12 \pm 1.01$ and 4.76 \pm 3.78 , respectively), especially if it was compared with the result of control and $1 \mathrm{mM}$ melatonin treated semen samples (Table 4). This indicates that buffalo semen treatment with melatonin $(0.1 \mathrm{mM})$ during cryopreservation process resulting in DNA protection which consequently protected the fertilization process and the resultant embryos. Looking through Table 5 of the effect of melatonin supplementation to buffalo semen diluent medium on the sperm in vitro fertilizing capacity, finding that there was a significant increase $(p<0.01)$ in the fertilization rate of buffalo semen samples treated with $0.1 \mathrm{mM}$ of melatonin (57.89), compared with the result of control and $1 \mathrm{mM}$ melatonin treated semen samples (23.72 and 23.21, respectively). The results of the current study indicate that, $0.1 \mathrm{mM}$ of melatonin is an ideal melatonin concentration enhancing sperm in vitro fertilization potentials. Also, there was a significant increase $(p<0.05)$ in the cleavage rate, morula stage and blastocyst rate resulting from fertilization of fresh qualified buffalo oocytes with buffalo sperms cells treated with 0.1 and $0.25 \mathrm{mM}$ of melatonin compared with control and $1 \mathrm{mM}$ melatonin.

In conclusion, the role of melatonin in enhancing the antioxidant activity of buffalo sperm cells, decreasing the rate of lipid peroxidation and DNA fragmentation was reflected in enhancement of the spermin vitro fertilization potentials and the rate of blastocyst harvesting.

\section{Discussion}

Naturally, seminal fluid contains melatonin (Bornman et al., 1989) and the spermatozoa reportedly possess membrane melatonin receptors (Bornman et al., 1989; Van Vuuren et al., 1992). Removing of buffalo seminal plasma during the cryopreservation process deprives the sperm cells from important elements in between melatonin. The current study clarified that melatonin has some fantastic protecting and enhancing functions on the post thawing buffalo semen characteristic in a dose dependent trend. Addition of 0.1 $\mathrm{mM}$ melatonin to the semen diluent is sufficiently effective to improve buffalo spermatozoa fertilizing ability and in vitro fertilizing potentials. These results came in agreement with (Fujinoki, 2008; Du Plessis et al., 2010; Succu et al., 2011) who reported that in vitro melatonin addition to hamster, human and ram spermatozoa, respectively had beneficial effects on their total progress motility. Moreover, Succu et al. (2011) reported that those effects of melatonin might be built on its role in enhancing the total ATP level in the sperm cells after treatment. 
While our results disagreed with Bornman et al. (1989); Sliwa and Stochmal (2001) and Gwayi and Bernard (2002) who reported that melatonin played no important role in the sperm motility. This disagreement might be attributed to species difference or differences in treatment doses and methodology or due to the inhibitory effect of ethanol that was used in melatonin dissolving through $\mathrm{pH}$ changing which directly affected not only the sperm motility but also the other aspects of sperm characteristics (Gwayi and Bernard, 2002). Where, the high concentrations of melatonin inhibited the quality of sperm motility in rats (Gwayi and Bernard, 2002). Additionally, melatonin at $0.1 \mathrm{mM}$ enhanced the acrosomal integrity and viability index of buffalo sperm cells. This melatonin improving effect might be due to a potent scavenging effect of melatonin on $\mathrm{NO}$ and Reactive Oxygen Species (ROS) that directly and indirectly affect the sperm viability by triggering the sperm apoptosis (Du Plessis et al., 2010; Espino et al., 2011). Therefore, the beneficial effect of melatonin on the freezability and in vitro fertilizing potentials may be attributed to its positive effect on antioxidant enzymes. Melatonin addition at $0.1 \mathrm{mM}$ augments the activities of GSH, superoxide dismutase antioxidant enzymes. GSH was very abundant intracellular free radical scavenger and antioxidant. It had been reported that melatonin stimulates the rate limiting enzyme $\gamma$-glutamylcysteine synthase, thereby increasing intracellular GSH concentrations (Urata et al., 1999). The results of the current study as shown in Table 2 throw an illuminating proof on these previous facts where it had been observed that melatonin addition to buffalo semen at $0.1 \mathrm{mM}$ enhanced the level of GSH $(106.66 \pm 12.03)$. Till the current study the relationship between melatonin and glutathione level in buffalo semen hasn't been detected yet; although, this relationship had been discovered in other cell types and tissues like brain tissues (Floreani et al., 1997; Martin et al., 2000). Furthermore, melatonin treatments augment the activities of other antioxidants (Gitto et al., 2001), like Superoxide Dismutase (SOD) (Reiter et al., 1998). The results of the current study came in harmony with the previous reports, where it has been observed that melatonin treatment to buffalo semen at $0.1 \mathrm{mM}$ augment the level of SOD $(73.67 \pm 5.37)$ (Table $2)$. So, melatonin is an effective factor in lowering molecular damage under conditions of elevated oxidative stress (Reiter, 1998; Reiter and Tan, 2003). Moreover, as shown in Table 2 there was a significant $(p<0.05)$ decrease in the level of lipid peroxidation in the membrane of the cryopreserved buffalo sperms treated with $0.1 \mathrm{mM}$ of melatonin $(11.00 \pm 1.73)$. Indicating that there was a significant enhancement in the Total Antioxidant Activity (TAC) of the cryopreserved buffalo semen treated with $0.1 \mathrm{mM}$ of melatonin by increasing its active enzymes that compete the free radicles (ROS) and this was reflected by decreasing the level of lipid peroxidation in buffalo sperm cells that was characterized naturally by high level of unsaturated fatty acids. This result came in agreement with Sarabia et al. (2011) and Hardeland et al. (2011) who reported that melatonin has powerful ability to purify peroxide radicals (ROO-) and consequently lipid peroxidation.

In Summary, melatonin addition to buffalo semen can improve its rate of cryopreservation by decreasing the rate of its destruction. In addition, there was a significant increase $(p<0.01)$ in fertilization rate of buffalo semen samples treated with $0.1 \mathrm{mM}$ of melatonin (57.89). The significant effect of melatonin on IVF outcomes (Table 5) might be explained firstly depending upon its effects in lowering the higher free radicals level that resulting in damaging and aging of the mitochondria (Bize et al., 1980). Moreover, melatonin via modulating the glutathione activity has the potency to improve mitochondrial health state and functions (Table 2). Active and healthy mitochondria have essential roles during fertilization process (Van Blerkom and Davis, 2007). It had been reported that healthy condition of mitochondria was important for several cellular activities; like ATP production (Mtango et al., 2008), regulation of cell survival (Dumollard et al., 2007). In addition, mitochondria play a vital role in signal transduction, oxygen sensing and maintenance of the cellular homeostasis especially calcium oscillations (Gutierrez et al., 2006; Quintero et al., 2006). Calcium oscillations are very important for fertilization, embryonic cell-cycle transition and embryonic axis establishment (Whitaker, 2008). So, melatonin by enhancing the mitochondrial healthy condition might share indirectly in all of these processes. Secondly, the improving effect of melatonin on IVF outcomes might be attributed depending upon melatonin antioxidant activity. Where, it was stated that the balance between ROS production and scavenging was an important factor for acquisition of in vitro fertilizing ability (De Lamirande et al., 1997), as it had been observed that high level of ROS had the capability to inhibit sperm-oocyte fusion (Aitken et al., 1993). Moreover, Ishizuka et al. (2000) concluded that melatonin significantly stimulated and supported fertilization and early mouse embryo development at concentration between $10^{-6}$ and $10^{-4} \mathrm{M}$ through its ROS scavenging action. So, in harmony with the previous studies and according to the current results, melatonin has a powerful antioxidant capacity (Table 2 and 6). Thirdly, the augmenting effect of melatonin on IVF outcomes might be attributed to the effects of melatonin on glutathione manipulation. In this area, glutathione was considered as the major intracellular free thiol that had important biological functions during cellular proliferation, amino acid transport, protein and DNA synthesis, reduction of disulfides; as well as it protects 
cells against oxidation (Gasparrini et al., 2000; Luberda 2005). In fact, several investigators reported that the reduction of sperm nuclear disulfide bonds was required to induce sperm nuclear decondensation as the first step of Male Pronuclear (MPN) formation (Perreault, 1990) and glutathione was an important factor for this reduction (Sutovsky and Schatten, 1997). Consequently, it promotes MPN formation following sperm in vitro penetration (Zuelke et al., 2003), as shown in Table 2 and 5. Moreover, it promotes the development of preimplantation-stage of mouse embryos (Gardiner and Reed, 1994), which came in harmony with the results of the current study (Table 6). Moreover, Fernandez et al. (1995) and Ishizuka et al. (2000) noted that melatonin affect the oocytes development; sustain fertilization and early embryo development after IVF in rats and mice.

\section{Conclusion}

The present data demonstrated that the presence of melatonin in the freezing extender at concentrations of $0.1 \mathrm{mM}$ improved the freezability and in vitro fertilizing potentials of buffalo spermatozoa. The current results also suggested that the protective effect of melatonin on the cryopreserved spermatozoa is directly related to the elevated antioxidant capacity, reduction of lipid peroxidation and protection of sperm DNA from deterioration.

\section{Acknowledgement}

We wish to thank Dr. H. M. Hassen (ARRI) for the helpful effort in the DNA analysis (Comet assay) and critical reading of the comet results.

\section{Funding Information}

This work was supported by financial aids from Animal Reproduction Research Institute-Giza (Egypt) and Faculty of Veterinary Medicine Benha University (Egypt).

\section{Author's Contributions}

Mohamed El-Raey and M.R. Badr: Performed the chemical analysis and IVEP procedures and manuscript publishing.

Z.M. Rawash: Collected the semen sample and prepared it and performed the ordinary semen analysis procedures and semen extension.

G.M. Darwish: Achieved manuscript writing and statistics besides sharing in IVEP procedures.

\section{Ethics}

Authors should address any ethical issues that may arise after the publication of this manuscript (There is no any ethical issues that may arise after publication of this manuscript).

\section{References}

Adriaens, I., P. Jacquet, R. Cortvrindt, K. Janssen and J. Smitz, 2006. Melatonin has dose-dependent effects on folliculogenesis, oocyte maturation capacity and steroidogenesis. Toxicology, 228: 333-343.

DOI: 10.1016/j.tox.2006.09.018

Agarwal, A. and S.A. Prabakaran, 2005. Mechanism, measurement and prevention of oxidative stress in male reproductive physiology. Ind. J. Exp. Biol., 43: 963-974. PMID: 16315393

Ahn, H.J. and I.H. Bae, 2004a. Effects of Melatonin on the Meiotic Maturation of Mouse Oocytes in vitro. Kor. J. Fertil. Steril., 31: 155-168.

Ahn, H.J. and I.H. Bae, 2004b. Effects of melatonin on the meiotic maturation of mouse oocytes in vitro. Korean J Fertil Steril, 31: 155-168.

Aitken, R.J., 1994. A free radical theory of male infertility. Reprod. Fertil. Dev., 6: 19-23. DOI: $10.1071 /$ RD9940019

Aitken, R.J., D. Harkiss and D. Buckingham, 1993. Relationship between iron-catalysed lipid peroxidation potential and human sperm function. J. Reprod. Fertil., 98: 257-265.

DOI: $10.1530 /$ jrf.0.0980257

Alvarez, J.G. and B.T. Storey, 2005. Differential incorporation of fatty acids into and peroxidative loss of fatty acids from phospholipids of human spermatozoa. Mol. Reprod. Dev., 42: 334-346. DOI: $10.1002 / \mathrm{mrd} .1080420311$

Ashrafi, I., H. Kohram, H. Naijian, M. Bahreini and M. Poorhamdollah, 2011. Protective effect of melatonin on sperm motility parameters on liquid storage of ram semen at $5^{\circ} \mathrm{C}$. African J. Biotechnol., 10: 6670-6674. DOI: $10.5897 / \mathrm{AJB} 11.1020$

Aurich, J.E., U. Schönherr, H. Hoppe and C. Aurich, 1997. Effects of antioxidants on motility and membrane integrity of chilled-stored stallion semen. Theriogenology, 48: 185-192. DOI: $10.1016 / \mathrm{S} 0093-691 \mathrm{X}(97) 84066-6$

Badr, M.R., 2009. Effects of supplementation with amino acids on in vitro buffalo embryo development in defined culture media. Global Veterinaria, 3: 407-413.

Bize, I.B., L.W. Oberley and H.P. Morris, 1980. Superoxide dismutase and superoxide radical in Morris hepatomas. Cancer Res., 40: 3686-3693. PMID: 6254638

Boe-Hansen, G.B., 2005. Hydrogen peroxide alters the physical state and function of the plasma membrane of pulmonary artery endothelial cells. J. Cell Phys., 20: 362-374.

Bornman, M.S., J.M.C. Oosthuizen, H.C. Barnard, G.W. Schulenburg, P. Boomker and S. Reif, 1989. Melatonin and Sperm Motility/Melatonin und Spermatozoenmotilität. Andrologia, 21: 483-485. DOI: 10.1111/j.1439-0272.1989.tb02456.x 
Brezezinska-Slevbodzinska, E., A.B. Slebodzmski, B. Pietras and G. Wieczorek, 1995. Antioxidant effect of vitamin $\mathrm{E}$ and glutathione on lipid peroxidation in boar semen plasma. Biol. Trace Elem. Res., 47: 69-74. DOI: $10.1007 / \mathrm{BF} 02790102$

Casao, A., N. Mendoza, R. Pérez-Pé, A. Grasa and J.A. Abecia et al., 2010. Melatonin prevents capacitation and apoptotic-like changes of ram spermatozoa and increases fertility rate. J. Pineal Res., 48: 39-46. DOI: 10.1111/j.1600-079X.2009.00722.x

Cerolini, S., A. Maldjian, P. Surai and R. Noble, 2000. Viability, susceptibility to peroxidation and fatty acid composition of boar semen during liquid storage. Anim. Reprod. Sci., 58: 99-111. DOI: $10.1016 / \mathrm{S} 0378-4320(99) 00035-4$

Chinoy, N.J., G.M. Ranga, H.N. Highland, K.J. D’Souza and E. Sequeira, 1992. A modified method for the differential staining of spermatozoa using alcoholic acidic silver nitrate. Int. J. Fertil., 37: 232-236. PMID: 1379996

Cortassa, S., M.A. Aon, R.L. Winslow and B. O'Rourke, 2004. A mitochondrial oscillator dependent on reactive oxygen species. Biopysic. J., 87: 2060-2073. DOI: 10.1529/biophysj.104.041749

De Lamirande, E. and C. Gagnon, 1992. Reactive oxygen species and human spermatozoa. I. Effects on the motility of intact spermatozoa and on sperm axonemes. J. Androl., 13: 368-378. PMID: 1331006

De Lamirande, E., H. Jiang, A. Zini, H. Kodama and C. Gagnon, 1997. Reactive oxygen species and sperm physiology. Rev. Reprod., 2:48-54.

DOI: $10.1530 /$ ror.0.0020048

Del Maestro, R.F., 1980. An approach to free radicals in medicine and biology. Acta Physiol. Scand Suppl., 492: 153-168. PMID: 6261528

Di Francesco, S., E. Mariotti, M. Tsantarliotou, A. Sattar and I. Venditto et al., 2009. Melatonin promotes in vitro sperm capacitation in buffalo (bubalus bubalis). Argentina. Reprod. Fertil. Dev., 22: 311-312.

DOI: 10.1071/RDv22n1Ab311

Du Plessis, S.S., K. Hagenaar and F. Lampiao, 2010. The in vitro effects of melatonin on human sperm function and its scavenging activities on $\mathrm{NO}$ and ROS. Andrologia, 42: 112-116.

DOI: $10.1111 / \mathrm{j} .1439-0272.2009 .00964 . x$

Dumollard, R., M. Duchen and J. Carroll, 2007. The role of mitochondrial function in the oocyte and embryo. Curr. Top Dev. Biol., 77: 21-49. DOI: $10.1016 / \mathrm{S} 0070-2153(06) 77002-8$

Espino, J., A. Ortiz, I. Bejarano, G.M. Lozano and F. Monllor et al., 2011. Melatonin protects human spermatozoa from apoptosis via melatonin receptorand extracellular signal-regulated kinase-mediated pathways. Fertil. Steril., 95: 2290-2296.

DOI: 10.1016/j.fertnstert.2011.03.063
Fernandez, B., E. Diaz, M.D. Colmenero and B. Diaz, 1995. Maternal pineal gland participates in prepubertal rats' ovarian oocyte development. Anat. Rec., 243: 461-465. DOI: 10.1002/ar.1092430408

Flohe, L. and F. Otting, 1984. Superoxide dismutase assays. Methods Enzymol., 105: 93-104. DOI: 10.1016/S0076-6879(84)05013-8

Floreani, M., S.D. Skaper, L. Facci, M. Lipartiti and P. Giusti, 1997. Melatonin maintains glutathione homeostasis in kainic acid-exposed rat brain tissues. FASEB J., 11: 1309-1315. PMID: 9409550

Fujinoki, M., 2008. Melatonin-enhanced hyperactivation of hamster sperm. Reproduction, 136: 533-541. DOI: 10.1530/REP-08-0202

Gardiner, C.S. and D.J. Reed, 1994. Status of glutathione during oxidant-induced oxidative stress in the preimplantation mouse embryo. Biol. Reprod., 51: 1307-1314. DOI: 10.1095/biolreprod51.6.1307

Gasparrini, B., G. Neglia, R.D. Palo, G. Campanile and L. Zicarelli, 2000. Effect of cysteamine during in vitro maturation on buffalo embryo development. Theriogenology, 54: 1537-1 542. PMID: 11191875

Gitto, E., D.X. Tan, R.J. Reiter, M. Karbownik and L.C. Manchester et al., 2001. Individual and synergistic antioxidative actions of melatonin: Studies with vitamin $\mathrm{E}$, vitamin $\mathrm{C}$, glutathione and desferrrioxamine (desferoxamine) in rat liver homogenates. J. Pharm. Pharmacol., 53: 1393-1401. DOI: $10.1211 / 0022357011777747$

Griveau, J.F., E. Dumont, P. Renard, J.P. Callegari and D. Le Lannou, 1995. Reactive oxygen species, lipid peroxidation and enzymatic defence systems in human spermatozoa. J. Reprod. Fertil., 103: 17-26. DOI: 10.1530/jrf.0.1030017

Gutierrez, J., S.W. Ballinger, V.M. Darley-Usmar and A. Landar, 2006. Free radicals, mitochondria and oxidized lipids the emerging role in signal transduction in vascular cells. Circ. Res., 99: 924-932. DOI: 10.1161/01.RES.0000248212.86638.e9

Gwayi, N. and R.T.F. Bernard, 2002. The effects of melatonin on sperm motility in vitro in Wistar rats. Andrologia, 34 391-396. DOI: 10.1046/j.1439-0272.2002.00522.x

Hardeland, R., D.P. Cardinali, V. Srinivasan, D.W. Spence and G.M. Brown et al., 2011. Melatonin-A pleiotropic, orchestrating regulator molecule. Prog. Neurobiol., 93: 350-384. DOI: $10.1016 /$ j.pneurobio.2010.12.004

Henkel, R., 2005. The impact of oxidants on sperm function. Andrologia, 37: 205-206. DOI: 10.1111/j.1439-0272.2005.00699.x

Hughes, C.M., S.E.M. Lewis, V.J. McKelvey-Martin and W. Thompson, 1996. A comparison of baseline and induced DNA damage in human spermatozoa from fertile and infertile men, using a modified comet assay. Mol. Hum. Reprod., 2: 613-619.

DOI: $10.1093 /$ molehr/2.8.613 
Ishizuka, B., Y. Kuribayashi, K. Murai, A. Amemiya and M.T. Itoh, 2000. The effect of melatonin on in vitro fertilization and embryo development in mice. $\mathrm{J}$. Pineal Res., 28: 48-51.

DOI: 10.1034/j.1600-079x.2000.280107.x

Jeulin, C., J.C. Soufir, P. Weber, D. Laval-Martin and R. Calvayrac, 1989. Catalase activity in human spermatozoa and seminal plasma. Gamet Res., 24: 185-196. DOI: $10.1002 / \mathrm{mrd} .1120240206$

Kang, J.T., O.J. Koo, D.K. Kwon, H.J. Park and G. Jang et al., 2009. Effects of melatonin on in vitro maturation of porcine oocyte and expression of melatonin receptor RNA in cumulus and granulosa cells. J. Pineal Res., 46: 22-28. DOI: 10.1111/j.1600-079X.2008.00602.x

Kantola, M., M. Saaranen and T. Vanha-Perttula, 1998. Selenium and glutathione peroxidase in seminal plasma of men and bulls. J. Reprod. Fertil., 83: 785-794. DOI: 10.1530/jrf.0.0830785

Luberda, Z., 2005. The role of glutathione in mammalian gametes. Reprod. Biol., 5: 5-17. PMID: 15821775

Marei, W.F., D.C. Wathes and A.A. Fouladi-Nashta, 2009. The effect of linolenic acid on bovine oocyte maturation and development. Biol. Reprod., 81: 1064-1072. DOI: 10.1095/biolreprod.109.076851

Martin, M., M. Macias, G. Escames, J. Leon and D. Acua-Castroviejo, 2000. Melatonin but not vitamins $\mathrm{C}$ and $\mathrm{E}$ maintains glutathione homeostasis in t-butyl hydroperoxide-induced mitochondrial oxidative stress. FASEB J., 14: 1677-1679.

Martino, A., T. Mogas, M.J. Palomo and M.T. Paramio, 1994. Meiotic competence of prepubertal goat oocytes. Theriogenology, 41: 969-980.

DOI: 10.1016/0093-691X(94)90512-H

Maxwell, W.M.C. and P.F. Watson, 1996. Recent progress in the preservation of ram semen. Anim. Reprod. Sci., 42: 55-65.

DOI: $10.1016 / 0378-4320(96) 01544-8$

Mayo, J.C., R.M. Sainz, H. Uria, I. Antolin and M.M. Esteban et al., 1998. Melatonin prevents apoptosis induced by 6-hydroxydopamine in neuronal cells: Implications for Parkinson's disease. J. Pineal Res., 24: 179-192.

DOI: 10.1111/j.1600-079X.1998.tb00531.x

Mohammed, K.M., M.S. Ziada and G.M. Darwish, 1998. Practical trials for freezing semen of buffalo and Friesian bulls: Effect of various regimens of freezing, different milk extenders and types of straws packages on post-thawing semen characters. Assiut Vet. Med. J., 39: 70-93.

Morisawa, M., 1994. Cell signaling mechanisms for sperm motility. Zoolog. Sci., 11: 647-662. PMID: 7765853
Mtango, N.R., A.J. Harvey, K.E. Latham and C.A. Brenner, 2008. Molecular control of mitochondrial function in developing rhesus monkey oocytes and preimplantation-stage embryos. Reprod. Fertil. Dev., 20: 846-859. DOI: 10.1071/RD08078

Parrish, J.J., J. Susko-Parrish, M.A. Winer and N.L. First, 1988. Capacitation of bovine sperm by heparin. Biol. Reprod., 38: 1171-1180.

DOI: $10.1095 /$ biolreprod38.5.1171

Perreault, S.D., 1990. Regulation of Sperm Nuclear Reactivation during Fertilization. In: Fertilization in Mammals, Bavister, B.D., J. Cummins and E.R.S. Roldan (Eds.), Norwell, MA: Serono Symposia, USA, pp: 285-296.

Placer, Z.A., L.L. Cushman and B.C. Johnson, 1966. Estimation of product of lipid peroxidation (malonyl dialdehyde) in biochemical systems. Anal. Biochem., 16: 359-364. DOI: 10.1016/0003-2697(66)90167-9

Quintero, M., S.L. Colombo, A. Godrey and S. Moncada, 2006. Mitochondria as signaling organelles in the vascular endothelium. Proc. Natl. Acad. Sci. USA, 103: 5379-5384. DOI: $10.1073 /$ pnas.0601026103

Reiter, R.J. 1998. Oxidative damage in the central nervous system: Protection by melatonin. Prog. Neurobiol, 56: 359-384. DOI: 10.1016/S0301-0082(98)00052-5

Reiter, R.J. and D.X. Tan, 2003. Melatonin: A novel protective agent against oxidative injury of the ischemic/reperfused heart. Cardiovasc. Res., 58: 10-19. DOI: 10.1016/S0008-6363(02)00827-1

Reiter, R.J., 1991. The Pineal Gland: Reproductive Interactions. In: Vertebrate Endocrinology: Fundamental and Biomedical Implications, Pang, P.K.T. and M.P. Schreibman (Eds.), Academic Press, San Diego, pp: 269-310.

Reiter, R.J., J.M. Guerrero, J.J. Garcia and D. AculaCastroviejo, 1998. Reactive oxygen intermediates, molecular damage and Aging: Relation to melatonin. Ann. N.Y. Acad. Sci., 854: 410-424. DOI: 10.1111/j.1749-6632.1998.tb09920.x

Reitman, S. and S. Frankel, 1957. A Colorimetric methodfor the determination of serum glutamic oxaloacetic trans-aminase and serum glutamic pyruvic transminase. Am. J. Clini. Pathol., 28: 56-63.

Reppert, S.M., C. Godson, C.D. Mahle, D.R. Weaver and S.A. Slaugenhaupt et al., 1995. Molecular characterization of a second melatonin receptor expressed in human retina and brain: The Mel1b melatonin receptor. Proc. Natl. Acad. Sci. USA, 92:8734-8738. DOI: 10.1073/pnas.92.19.8734

Reppert, S.M., D.R. Weaver and T. Ebisawa, 1994. Cloning and characterization of a mammalian melatonin receptor that mediates reproductive and circadian responses. Neuron, 13: 1177-1185. DOI: $10.1016 / 0896-6273(94) 90055-8$ 
Sarabia, L., O. Espinoza-Navarro, I. Maurer, C. Ponce and E. Bustos-Obreḡn, 2011. Protective effect of melatonin on damage in the sperm parameters of mice exposed to diazinon. Int. J. Morphol., 29: 1241-1247.

DOI: $10.4067 /$ S0717-95022011000400029

Sedlak, J. and R.H.C. Lindsay, 1968. Estimation of total, protein-bound and nonprotein sulfhydryl groups in tissue with Ellman's reagent. Anal. Biochem., 25: 192-205. DOI: 10.1016/0003-2697(68)90092-4

$\mathrm{Si}, \mathrm{Y}$. and P. Olds-Clarke, 2000. Evidence for the involvement of calmodulin in mouse sperm capacitation. Biol. Reprod., 62: 1231-1239. DOI: $10.1095 /$ biolreprod62.5.1231

Sliwa, L. and E. Stochmal, 2001. The effect of melatonin on directional motility of human sperm under in vitro conditions. Folia Med. Cracov., 42: 123-128. PMID: 12353419

Stubbs, C.D. and A.D. Smith, 1984. The modification of mammalian membrane polyunsaturated fatty acid composition in relation to membrane fluidity and function. Biochimica et Biophysica Acta Rev. Biomembranes, 779: 89-137. DOI: $10.1016 / 0304-4157(84) 90005-4$

Suarez, S.S. and H.C. Ho, 2003. Hyperactivated motility in sperm. Reprod. Domes. Anim., 38: 119-124. DOI: 10.1046/j.1439-0531.2003.00397.x

Succu, S., F. Berlinguer, V. Pasciu, V. Satta and G.G. Leoni et al., 2011. Melatonin protects ram spermatozoa from cryopreservation injuries in a dose-dependent manner. J. Pineal Res., 50: 310-318. DOI: 10.1111/j.1600-079X.2010.00843.x

Sutovsky, P. and G. Schatten, 1997. Depletion of glutathione during bovine oocyte maturation reversibly blocks the decondensation of the male pronucleus and pronuclear apposition during fertilization. Biol. Reprod., 56: 1503-1512.

DOI: 10.1095/biolreprod56.6.1503

Tan, D.X., L.C. Manchester, M.P. Terron, L.J. Flores and R.J. Reiter, 2007. One molecule, many derivatives: A never-ending interaction of melatonin with reactive oxygen and nitrogen species? J. Pineal Res., 42: 28-42.

DOI: 10.1111/j.1600-079X.2006.00407.x
Tanyildizi, S., T. Bozkurt, O. Çiftçi, F. Sakin, 2006. in vitro effects of melatonin on hyaluronidase activity and sperm motility in bull semen. Turk. J. Vet. Anim. Sci., 30: 89-93. Tietz, N.W., 1976. Fundamentals of Clinical Chemistry. W.B. Saunders Company, Philadelphia.

Totey, S.M., G. Singh, M. Taneja, C.H. Pawshe and G.P. Talwar, 1992. in vitro maturation, fertilization and development of follicular oocytes from buffalo (Bubalus bubalis). J. Reprod. Fertil, 95: 597-607. DOI: 10.1530/jrf.0.0950597

Urata, Y., S. Honma, S. Goto, S. Todoroki and T. Iida et al., 1999. Melatonin induces $\gamma$-glutamylcysteine synthetase mediated by activator protein-1 in human vascular endothelial cells. Free Radic. Biol. Med., 27: 838-847. DOI: 10.1016/S0891-5849(99)00131-8

Van Blerkom, J. and P. Davis, 2007. Mitochondrial signaling and fertilization. Mol. Hum. Reprod, 13: 759-770. DOI: 10.1093/molehr/gam068

Van Vuuren, R.J.J., M.J. Pitout, C.H. Van Aswegen and J.J. Theron, 1992. Putative melatonin receptor in human spermatozoa. Clin. Biochem., 25: 125-127.

Whitaker, M., 2008. Calcium signalling in early embryos. Philosophical Transactions Royal Society B Biological Sci., 363: 1401-1418. DOI: $10.1098 /$ rstb.2008.2259

Yanagimachi, R., 1994. Mammalian Fertilization. In: The Physiology of Reproduction, Knobil, E. and J. Neill (Eds.), Raven Press, New York, USA, pp: 189-317.

Yudin, A.I., W. Gottlieb and S. Meizel, 1988. Ultrastructural studies of the early events of the human sperm acrosome reaction as initiated by human follicular fluid. Gamete Res., 20: 11-24. DOI: $10.1002 / \mathrm{mrd} .1120200103$

Zuelke, K.A., S.C. Jeffay, R.M. Zucker and S.D. Perreault, 2003. Glutathione (GSH) concentrations vary with the cell cycle in maturing hamster oocytes, zygotes and pre-implantation stage embryos. Mol. Reprod. Dev., 64: 106-112.

DOI: $10.1002 / \mathrm{mrd} .10214$ 